\title{
Model ARIAS berbasis TSTS terhadap Kemampuan Berpikir Kritis Matematis Ditinjau dari Gaya Kognitif
}

\author{
Desmawati $^{*}$, Farida ${ }^{1}$ \\ ${ }_{1}^{1}$ Universitas Islam Negeri Raden Intan Lampung. Jalan Endro Suratmin, Sukarame, Bandar \\ Lampung 35133, Indonesia. \\ *Corresponding Author. E-mail: desmawati293@gmail.com
}

Received : 15-11-2017; Revised : 05-01-2018; Accepted : 29-01-2018

\begin{abstract}
Abstrak
Penelitian ini bertujuan untuk mengetahui apakah terdapat pengaruh model ARIAS berbasis model Two Stay Two Stray terhadap kemampuan berpikir kritis matematis. Penelitian ini merupakan penelitian Quasi Eksperimental Design. Pengujian hipotesis menggunakan analisis variansi dua jalan sel tak sama, Berdasarkan uji analisis variansi sel tak sama diperoleh bahwa terdapat pengaruh model ARIAS berbasis Two Stay Two Stray terhadap kemampuan berpikir kritis matematis dan terdapat pengaruh gaya kognitif terhadap kemampuan berpikir kritis matematis, dimana siswa dengan perlakuan pembelajaran menggunakan model pembelajaran ARIAS terintegrasi model pembelajaran TSTS terhadap kemampuan berpikir kritisnya lebih baik dibandingkan dengan siswa dengan perlakuan pembelajaran menggunakan metode ceramah yang ditinjau dari masing-masing gaya kognitif siswa. Kemampuan berpikir kritis matematis siswa dengan gaya kognitif field independent lebih baik daripada siswa dengan gaya kognitif field dependent. Tidak terdapat interaksi antara perlakuan pembelajaran dan gaya kognitif terhadap kemampuan berpikir kritis matematis.
\end{abstract}

Kata kunci: : ARIAS; Berpikir Kritis Matematis, Gaya Kognitif, dan TSTS.

\begin{abstract}
This study aims to determine whether there is the influence of ARIAS model based on Two Stay Two Stray model to critical thinking ability mathematically. This research is Quasi-Experimental Design research. Hypothesis testing using variance analysis of two different cell roads Based on the test of cell variance analysis is not the same obtained that there is influence of ARIAS model based on Two Stay Two Stray to critical mathematical thinking ability and there is influence of cognitive style to critical thinking skill mathematically, where student with treatment of learning using integrated learning model ARIAS TSTS learning model on the ability of critical thinking is better than students with learning treatment using lecture methods in terms of each student's cognitive style. The students' mathematical critical thinking ability with independent field cognitive style is better than students with cognitive field dependent style. There is no interaction between learning and cognitive styles to critical mathematical thinking skills.
\end{abstract}

Keywords : ARIAS; Mathematical Critical Thinking, Cognitive Style, and TSTS.

\section{PENDAHULUAN}

Kebutuhan atau tuntutan pendidikan nasional yaitu mewujudkan kegiatan pembelajaran dan suasana belajar agar siswa dapat lebih aktif dalam perkembangan potensi pada dirinya agar memiliki pengendalian diri, kekuatan spritual keagamaan, kecerdasan, kepribadian, dan akhlak mulia, serta keterampilan yang dilakukan dirinya, masyarakat, bangsa, dan negara, hal ini tertulis pada UU No.20 Tahun 2003 (Eni, Marli, \& Margiati, 2014). Untuk menunjang perkembangan potensi diri siswa dan meningkatkan kecerdasan memproses yang tertulis dalam Undang-Undang 
Desimal, 1 (1), 2018 - 66

Desmawati, Farida, Fraulein Intan Suri

tersebut maka diperlukan adanya kegiatan pembelajaran dan pendidikan.

$$
\text { Undang-undang republik }
$$

Indonesia no.2 tahun 2009 dalam menjelaskan bahwa pendidikan ialah usaha sadar dan terencana dalam menciptakan suasana belajar dan proses pembelajaran agar peserta didik secara aktif mengembangkan potensi dirinya untuk memiliki kekuatan spiritual keagamaan, pengendalian diri, kepribadian, kecerdasan, akhlak mulia, serta keterampilan yang diperlukan dirinya, masyarakat, bangsa, dan Negara (Sukring, 2016). Maka dari itu, tanpa melalui proses pendidikan tidak mungkin suatu manusia dapat berkembang sejalan dengan aspirasi (cita-cita) untuk maju, sejahtera dan bahagia. Sejalan dengan hal itu tentunya pendidikan tidak bisa dipisahkan dengan mata pelajaran Matematika, karna pelajaran matematika adalah pelajaran yang kompleks dari semua tingkatan.

Pelajaran matematika sebagai salah satu ilmu yang tidak kalah pentingnya dalam upaya meningkatkan mutu pendidikan dan kehidupan bangsa. Paradigma dalam pembelajaran matematika membawa dampak pada penekanan terhadap perubahan siswa dalam proses pembelajaran. Perubahan tersebut mengubah fokus seluruh paradigma dalam suatu pendidikan matematika di seluruh dunia (Rahmadi, 2015). Pandangan orang umumnya mengatakan bahwa matematika hanyalah penemuan manusia biasa, padahal pelajaran matematika salah satu mata pelajaran yang memiliki manfaat besar dalam kehidupan (Sari, 2016). Salah satu tujuan pembelajaran matematika adalah meningkatkan kemampuan berfikir kritis dalam matematik, karena Kecerdasan memproses dapat ditingkatkan melalui keterampilan berpikir (Mujib, 2016).

Berpikir kritis adalah cara berpikir bukan sekedar menghafal materi tetapi penggunaan dan manipulasi bahan-bahan yang di pelajari dalam situasi baru sehingga dikategorikan sebagai berpikir lebih tinggi (Setyowati \& Subali, 2011). Kemampuan berpikir dengan kritis yaitu kemampuan yang esensial baik untuk pekerjaan, kehidupan dan berfungsi pada seluruh aspek kehidupan yang lainnya (Liberna, 2015). Menyadari betapa pentingnya meningkatkan kemampuan berpikir kritis terutama di sekolah, maka perlu peran siswa secara aktif dalam kegiatan pembelajaran. Namun faktanya siswa tidak bisa mengolah apa yang guru berikan (pembelajaran konvensional), sehingga siswa cenderung tidak aktif dan kemampuan berpikir kritis kurang terlatihkan. Ketika siswa diberi permasalahan siswa cenderung mengeluarkan jawaban yang sama, dan terkadang hanya mengikuti contoh yang sudah ada, belum tampak adanya penemuan ide baru. Begitu juga guru kurang mengarahkan dan memberikan motivasi agar siswa dapat mengaitkan masalah yang dialami dengan kehidupan sehari-hari. Hal itu menyebabkan kurangnya kemampuan berpikir kritis dalam belajar matematika (Wulan Rachmayanti, 2016). Tak bisa dipunngkiri rendahnya hasil belajar siswa juga disebabkan oleh rendahnya kemampuan berfikir kritis matematis (Herdianawati, Fitrihidajati, \& Purnomo, 2013; Mujib, 2016)

Kemampuan berpikir kritis matematis siswa yang dipengaruhi oleh beberapa faktor, salah satunya adalah cara pembelajaran menggunakan metode ceramah, hanyalah guru yang aktif sedangkan siswa hanya mendengarkan. Faktor lainnya adalah gaya belajar atau gaya kognitif, karena gaya kognitif masing-masing siswa tidak selalu sama (Happy \& Widjajanti, 2014; Mujib, 2016). Karena adanya perbedaan siswa dalam menangkap informasi dan 
Desimal, 1 (1), 2018 - 67

Desmawati, Farida, Fraulein Intan Suri

menggunakan strategi untuk menyelesaikan suatu latihan yang guru berikan. Untuk mengatasi hal tersebut perlu adanya usaha dengan membuat suasana belajar menyenangkan dengan menumbuhkan motivasi, meningkatan minat dan rasa percaya pada diri sendiri, serta kegiatan pembelajaran matematika agar menarik perhatian dan membuat siswa tidak merasa takut saat belajar matematika yaitu dengan cara menggunakan model pembelajaran (Mujib, 2016). Salah satu faktor yang diduga berpengaruh terhadap berhasil atau tidaknya suatu proses pendidikan adalah proses pembelajaran yang berlangsung di kelas (Putra, 2016).

Merujuk hal itu maka penulis mencoba memberikan salah satu solusi yang bisa menjadi alternatif para pendidik dalam upaya meningkatan kemampuan berfikir matematis siswa sehingga siswa termotivasi dan menambahkan minat belajar dalam matematika. Salah satu alternatif model pembelajaran yang mampu memberikan motivasi dan minat belajar siswa adalah ARIAS (Andriyani, 2013). ARIAS adalah usaha pertama dengan menanamkan rasa yakin/percaya diri siswa yang dilakukan pada kegiatan pembelajaran yang ada kesesuaiannya dengan kehidupan sehari-hari, berusaha menarik dan menumbuhkan minat/perhatian siswa (Rahman, 2014). Namun dalam prosesnya, model pembelajaran yang memiliki beberapa langkah proses pembelajarannya dimana terdapat pembelajaran kooperatif dalam pelaksanaanya. Salah satu model pembelajaran yang dirasa cocok untuk diintegrasikan dengan ARIAS adalah TSTS. TSTS termasuk salah satu model pembelajaran kooperatif. TSTS atau dua tinggal dua tamu bertujuan untuk mengelolah apa yang diberikan oleh kelompok lain dan membagikan hasil yang didapat kepada kelompok lain (Abidin, 2012; Yunus \& Suyitno, 2013).

Berdasarkan penelitian yang pernah dilakukan bahwa melalui pembelajaran dengan ARIAS siswa lebih termotivasi dan aktif dalam kegiatan pembelajaran, hal tersebut berdampak pada meningkatnya kemampuan berpikir kritis matematis menjadi lebih besar pada pembelajaran dengan ARIAS dibandingkan dengan pembelajaran yang bersifat konvensional (Sulistyaningrum, Karyanto, \& Sunarno, 2015; Wulan Rachmayanti, 2016).

Kebaruan dalam tulisan ini adalah peneliti mencoba menerapkan Model pembelajaran ARIAS berbasis TSTS untuk melihat pengaruhnya terhadap kemampuan berpikir kritis matematis yang ditinjau dari gaya kognitif peserta didik. Sehingga penulis tertarik melakukan penelitian yang berjudul implementasi model ARIAS berbasis TSTS terhadap kemampuan berpikir kritis matematis ditinjau dari gaya kognitif peserta didik.

\section{METODE}

Dalam penelitian ini, penulis menggunakan metode penelitian eksperimen karena penulis akan mencari perbedaan treatment (perlakuan) tertentu. Jenis metode eksperimen yang digunakan adalah Quasy Experimental Design. Penelitian ini teknik sampling yang digunakan adalah teknik acak kelas (Random Sampling). Instrumen yang digunakan dalam penelitian ini adalah instrumen tes (tes kemampuan pemecahan masalah matematis peserta didik). Teknik analisis data dalam pengujian hipotesis menggunakan uji ANAVA dua jalan sel tak sama.

\section{HASIL DAN PEMBAHASAN}

Data kemampuan berpikir kritis matematis siswa pada mata pelajaran matematika materi persamaan 
Desimal, 1 (1), 2018 - 68

Desmawati, Farida, Fraulein Intan Suri

linear satu variabel dapat disajikan pada

Tabel

1.

berikut:

Tabel 1. Deskripsi Data Amatan Kemampuaan Berpikir Kritis Matematis Siswa

\begin{tabular}{cccccccc}
\hline Kelas & \multicolumn{4}{c}{ U } & \multicolumn{4}{c}{ Ukuran Tendensi Sental } & \multicolumn{2}{c}{ Ukuran Variansi } \\
& & $\boldsymbol{X}_{\text {Min }}$ & $\overline{\boldsymbol{X}}$ & Me & Mo & $\mathrm{R}$ & $\mathrm{S}$ \\
Eksperimen & 100 & 35 & 71,72 & 75 & 75 & 65 & 13,03 \\
Kontrol & 100 & 27 & 62,17 & 63 & 58 & 73 & 17,80 \\
\hline
\end{tabular}

Berdasarkan Tabel 1. tersebut, diketahui bahwa terdapat perbedaan nilai rata-rata kemampuan berpikir kritis matematis siswa antara kelas eksperimen dan kelas kontrol. Kelas ekperimen memiliki rata-rata kemampuan berpikir kritis matematis yang lebih tinggi dari kelas kontrol. Berdasarkan data yang telah diperoleh, hasil uji prasyarat yaitu uji normalitas menunjukkan bahwa data pada setiap kelas berasal dari populasi yang berdistribusi normal dan memiliki varians yang homogen. Selanjutnya dilakukan uji hipotesis dengan menggunakan uji analisis variansi (ANAVA) dua jalan sel tak sama pada taraf signifikansi $5 \%$.

Tabel 2. Rangkuman Analisis Variansi Dua Jalan Sel Tak Sama

\begin{tabular}{cllllll}
\hline & $J K$ & $d K$ & $R K$ & $F_{o b s}$ & $F a$ & Keputusan \\
Model Pembelajaran & 91,099 & 1 & 1040,490 & 4,768 & 3,982 & $H_{0 A}$ ditolak \\
$(A)$ & 185,431 & 1 & 2117,905 & 9,705 & 3,982 & $H_{0 B}$ ditolak \\
Gaya Kognitif $(B)$ & 2,055 & 1 & 22,901 & 0,105 & 3,982 & $H_{0 A B}$ diterima \\
$\quad$ Interaksi $(A B)$ & 14621,459 & 67 & 218,231 & & & \\
$\quad$ Galat & 14899,990 & 70 & & & & \\
Total & & & & & \\
\hline
\end{tabular}

Berdasarkan Tabel 2., dapat disimpulkan bahwa: (1) $H_{0 A}$ ditolak berarti terdapat pengaruh antara model pembelajaran ARIAS terintegrasi model pembelajaran TSTS dan pembelajaran konvensional terhadap kemampuan berpikir kritis matematis; (2) $H_{O B}$ ditolak berarti terdapat pengaruh antara gaya kognitif terhadap kemampuan berpikir kritis matematis; (3) $H_{0 A B}$ diterima berarti tidak terdapat interaksi antara perlakuan pembelajaran dengan kategori gaya kognitif siswa terhadap kemampuan berpikir kritis matematis. Berdasarkan perhitungan pada Tabel 2, diperoleh $H_{0 A}$ variabel kemampuan berpikir kritis matematis ditolak sehingga perlu dilakukan uji komparasi ganda menggunakan metode Scheffe' untuk melihat model pembelajaran dan gaya kognitif manakah yang lebih baik pada masing-masing varabel terikat. Berikut rangkuman rerata sel dan rerata marginal disajikan pada Tabel 3 .

Tabel 3. Rangkuman Rerata dan Rerata Marginal

\begin{tabular}{llll}
\hline \multicolumn{1}{c}{ Model Pembelajaran } & \multicolumn{2}{c}{$\begin{array}{c}\text { Berpikir Kritis } \\
\text { Matematis }\end{array}$} & Rerata Marginal \\
& FI & FD & \\
Model ARIAS + TSTS & 79,233 & 64.200 & 71.342 \\
Model Ceramah & 68.273 & 56.071 & 62.172 \\
Rerata Marginal & 73.378 & 60.136 & \\
\hline
\end{tabular}


Desimal, 1 (1), 2018 - 69

Desmawati, Farida, Fraulein Intan Suri

Berdasarkan Tabel 3, diketahui rataan marginal siswa yang memiliki gaya kognitif FI lebih baik dari siswa yang memiliki gaya kognitif FD dan perbedaan tersebut berbeda secara signifikan, sehingga dapat disimpulkan bahwa siswa yang memiliki gaya kognitif FI lebih baik dari siswa yang gaya kognitif FD terhadap kemampuan berpikir kritis matematis. Begitupun untuk siswa yang memperoleh perlakuan dengan model pembelajaran ARIAS Terintegrasi model pembelajaran TSTS lebih baik dibandingkan dengan siswa yang memperoleh pembelajaran konvensional.

Hasil analisis data secara keseluruhan baik ditinjau dari gaya kognitif menunjukkan bahwa rata-rata kemampuan berpikir kritis matematis siswa yang mendapatkan model pembelajaran ARIAS terintegrasi model pembelajaran TSTS lebih baik daripada siswa dengan metode konvensional. Untuk rata-rata gaya kognitif Field Independent (FI) pada kelas eksperimen (menggunakan model pembelajaran ARIAS + TSTS) yaitu 78,484 dan pada kelas kontrol rata-ratannya 68,273 . Untuk gaya kognitif Field Dependent (FD) pada kelas eksperimen rata-ratannya 64,200 dan pada kelas kontrol yaitu 56,071. Salah satu penyebab skor rata-rata hasil tes kemampuan berpikir kritis matematis siswa dari kelas eksperimen dan kelas kontrol berbeda-beda adalah proses pembelajaran menggunakan model pembelajaran ARIAS terintegrasi model pembelajaran TSTS yang menjadikan siswa belajar dengan optimal sehingga materi dipahami siswa lebih tinggi dan meningkatkan kemampuan berpikir kritis matematis. Karena model ARIAS terdiri dari lima komponen yaitu: Assurance (Percaya diri), Relevance (Sesuai dengan kehidupan siswa), Interest (Minat dan perhatian siswa), Assessment (Evaluasi) dan Satisfaction (Penguatan) sehingga tercipta pembelajaran aktif, kemudian diintegrasikan dengan model Two Stay
Two Stray yaitu sistem belajar berkelompok yang dapat melatih daya pikir dalam berdiskusi. Sedangkan pembelajaran menggunakan metode ceramah menekankan pada situasi peneliti/guru mengajar bukan situasi siswa belajar. Kondisi ini menyebabkan siswa kurang mampu untuk memahami materi yang diajarkan.

\section{SIMPULAN DAN SARAN}

Berdasarkan teori dan didukung oleh dengan hasil analisis dan pengolahan data serta mengacu pada perumusan masalah yang telah diuraikan, maka dapat disimpulkan bahwa terdapat pengaruh model ARIAS berbasis Two Stay Two Stray terhadap kemampuan berpikir kritis matematis dan terdapat pengaruh gaya kognitif terhadap kemampuan berpikir kritis matematis, dimana siswa dengan perlakuan pembelajaran menggunakan model pembelajaran ARIAS terintegrasi model pembelajaran TSTS terhadap kemampuan berpikir kritisnya lebih baik dibandingkan dengan siswa dengan perlakuan pembelajaran menggunakan metode ceramah yang ditinjau dari masing-masing gaya kognitif siswa. Kemampuan berpikir kritis matematis siswa dengan gaya kognitif field independent lebih baik daripada siswa dengan gaya kognitif field dependent. Tidak terdapat interaksi antara perlakuan pembelajaran dengan kategori gaya kognitif siswa.

Saran untuk penelitian selanjutnya adalah mencoba mengeksperimenkan model pembelajaran lain dan membandingkan dengan hasil penelitian ini model pembelajaran manakah yang lebih efektif dalam mempengaruhi kemampuan berpikir kritis siswa. Peninjauan kemampuan afektifpun perlu dilakukan guna melihat interaksi antara model dan kemampuan afektif lainnya. 
Desimal, 1 (1), 2018 - 70

Desmawati, Farida, Fraulein Intan Suri

\section{DAFTAR PUSTAKA}

Abidin, Z. (2012). Analisis kesalahan mahasiswa prodi pendidikan matematika fakultas tarbiyah IAIN Ar-Raniry dalam mata kuliah trigonometri dan kalkulus 1. Jurnal Ilmiah Didaktika, 13(1).

Andriyani, W. (2013). Keefektifan Model Pembelajaran Arias (Assurance, Relevance, Interest, Assessment, and Satisfaction) Untuk Meningkatkan Keterampilan Berpikir Kritis Siswa Pada Materi Larutan Penyangga Dan Hidrolisis Di SMA Negeri 12 Semarang (PhD Thesis). Universitas Negeri Semarang.

Eni, E., Marli, S., \& Margiati, K. Y. (2014). Peningkatan Aktivitas dan Hasil Pembelajaran IPA dengan Media Realia Kelas IV Sdn 11 Tanjung Lokang. Jurnal Pendidikan Dan Pembelajaran, 3(2).

Happy, N., \& Widjajanti, D. B. (2014). Keefektifan PBL ditinjau dari kemampuan berpikir kritis dan kreatif matematis, serta self-esteem siswa SMP. Jurnal Riset Pendidikan Matematika, 1(1), 48-57.

Herdianawati, S., Fitrihidajati, H., \& Purnomo, T. (2013). Pengembangan Lembar Kegiatan Siswa (LKS) Inkuiri Berbasis Berfikir Kritis pada Materi Daur Biogeokimia Kelas X. Jurnal BioEdu, 2(1), 99-104.

Liberna, H. (2015). Peningkatan Kemampuan Berpikir Kritis Matematis Siswa Melalui Penggunaan Metode Improve Pada Materi Sistem Persamaan Linear Dua Variabel. Formatif: Jurnal Ilmiah Pendidikan MIPA, 2(3), 190-197.

Mujib, M. (2016). Mengembangkan Kemampuan Berfikir Kritis Melalui Metode Pembelajaran Improve. AlJabar: Jurnal Pendidikan Matematika, 7(2), 167-180.

Putra, F. G. (2016). Pengaruh Model Pembelajaran Reflektif dengan Pendekatan Matematika Realistik
Bernuansa Keislaman terhadap Kemampuan Komunikasi Matematis. Al-Jabar : Jurnal Pendidikan Matematika, 7(2), 203-210.

Rahmadi, F. (2015). Pengembangan Perangkat Pembelajaran Berbasis Pemecahan Masalah Berorientasi pada Kemampuan Penalaran dan Komunikasi Matematika. Pythagoras: Jurnal Pendidikan Matematika, 10(2), 137-145. https://doi.org/10.21831/pg.v10i2. 9133

Sari, W. R. (2016). Pengembangan perangkat pembelajaran bangun ruang di SMP dengan pendekatan pendidikan matematika realistik. Jurnal Riset Pendidikan Matematika, 3(1), 109-121.

Setyowati, A., \& Subali, B. (2011). Implementasi pendekatan konflik kognitif dalam pembelajaran fisika untuk menumbuhkan kemampuan berpikir kritis siswa SMP kelas VIII. Jurnal Pendidikan Fisika Indonesia, $7(2)$.

Sukring, S. (2016). Pendidik dalam Pengembangan Kecerdasan Peserta Didik (Analisis Perspektif Pendidikan Islam ). Tadris: Jurnal Keguruan Dan Ilmu Tarbiyah, 1(1), 69-80.

Sulistyaningrum, D. E., Karyanto, P., \& Sunarno, W. (2015). Pengembangan Modul Berbasis Model Pembelajaran Arias untuk Memberdayakan Motivasi dan Berpikir Kritis Siswa pada Materi Ekosistem. INKUIRI Jurnal Pendidikan IPA, 4(1), 104-116.

Wulan Rachmayanti, N. 148060056. (2016). Penerapan Model Pembelajaran ARIAS (Assurance, Relevance, Interest, Assessment, Satisfaction) untuk Meningkatkan Kemampuan berpikir kritis dan kemampuan berpikir kreatif serta Dampaknya terhadap Motivasi Belajar Matematik Siswa SMA (masters). UNPAS.

Yunus, M., \& Suyitno, H. (2013). 
Desimal, 1 (1), 2018 - 71

Desmawati, Farida, Fraulein Intan Suri

Pembelajaran TSTS Berbasis

Konstruktivisme Berbantuan CD

Pembelajaran Untuk Menumbuhkan

Kemampuan Komunikasi Matematis

Siswa. Unnes Journal of Mathematics

Education Research, 2(1). 